\title{
GYDYTOJŲ ODONTOLOGŲ PADĖJĖJŲ DARBE PATIRIAMAS STRESAS: PIRMŲJU巳 DARBO METU PATIRTIS ODONTOLOGIJOS KLINIKOJE
}

\author{
Rasa Tamulienė, Emilė Gedeikytė, Daiva Mačiulienė \\ Kauno kolegija
}

\begin{abstract}
Raktažodžiai: gydytojų odontologų padèjëjai, darbe patiriamas stresas, pirmieji darbo metai.

Santrauka

Straipsnyje pristatomo tyrimo metu buvo siekiama atskleisti gydytojų odontologų padejejjų patiriamą stresą pirmaisiais darbo metais. Tyrime dalyvavo septynios gydytojų odontologų padejjèjos, turinčios vienerių metų darbo patirti odontologijos kabinete. Duomenų rinkimo metodas - pusiau struktūruotas interviu. Tyrimo metu surinktų duomenų analizè atlikta taikant aprašomosios bei turinio analizès metodus. Atlikto tyrimo rezultatai atskleide, kad pirmaisiais metais dèl darbe patiriamo streso gydytojų odontologų padèjëjai jautẻ ,nenorą nieko daryti“", pablogèjo jų santykiai su artimaisiais, dažniau buvo linkę savo išgyvenamas neigiamas emocijas išlieti ant kitų žmonių, jautė nenorą eiti ị darbą, dažniau save nuvertindavo, gana dažnai galvodavo apie darbą, net ji pabaigę. Daugiausia streso pirmaisiais darbo metais jiems kèlè santykiai su gydytoju odontologu bei kitais kolegomis, ịsiliejimo ị kolektyvą problemos, profesiniu igūdžių trūkumas, didelis darbo tempas ir darbo daugiafunkciškumas.
\end{abstract}

\section{Ivadas}

Darbe patiriamas stresas yra antra pagal dažnumą su darbu susijusi sveikatos problema Europos Sajungoje, kuri kasmet paliečia apie 28 procentus Europos Sajungos piliečių. Darbe patiriamas stresas neigiamai veikia ne tik darbuotojo sveikatą, tačiau ir pačią organizaciją bei šalies ekonomiką [3]. Tyrimai rodo, kad sveikatos priežiūros darbuotojai turi didesnę tikimybę patirti su darbu susijusi stresą dèl didelio darbo krūvio, darbo naktimis, aukštu reikalavimų darbui, viršvalandžių, nuolatos jaučiamos atsakomybės už kito žmogaus sveikatą ir gyvybę, ịtempto bendravimo su pacientais ir jų artimaisiais [5]. Stresas darbe ypač didelis pirmaisiais darbo metais dèl patiriamo realybės šoko, kai suvokiamas skirtumas tarp įsivaizduotos profesijos ir realybès [8]. Atlikus mokslinès literatūros analizę nustatyta, kad didžioji dalis nagrinèjamos tematikos tyrimų analizuoja slaugytojų patiriamą stresą pirmaisiais darbo metais $[1,4,7]$. Rasta viena studija apie ergoterapeutu patiriamą stresą pirmaisiais darbo metais [10]. Mokslinių tyrimų, analizuojančių gydytojų odontologų padejejjų darbe patiriamą stresą, nedaug. Nustatyta, kad jaunesniojo amžiaus, mažiau darbo patirties turintys odontologų padejejejai patiria aukštesnio lygmens su darbu susijusị stresą [12].

Tyrimo tikslas - atskleisti gydytojų odontologų padèjëjų darbe patiriamo streso raišką pirmaisiais darbo metais odontologijos klinikoje.

\section{Tyrimo objektas, medžiaga ir metodai}

Tyrimo objektas - gydytojų odontologų padèjèjų darbe patiriamas stresas pirmaisiais darbo metais odontologijos klinikoje.

Tyrimo organizavimas, eiga ir imties sudarymo principai. Tyrimas vyko 2020 metų vasario-balandžio mènesiais. Tyrimo metu buvo apklaustos septynios gydytojų odontologu padejejosos, kurių darbo patirtis yra vieneri metai. I tyrimo imtị buvo įtrauktos tik tos gydytojų odontologų padejejosos, kurios iki pradedamos dirbti odontologų padejjejomis nebuvo igijusios kitos darbinès patirties. Dèl paskelbtos COVID-19 pandemijos interviu buvo vykdomi nuotoliniu būdu. Vidutinè interviu trukmè - 30 minučių. Gavus tiriamujų leidimą, interviu buvo įrašomi, o vèliau transkribuojami.

Tyrimo priemonè, duomenų rinkimo ir analizės metodai. Tyrimo metu naudotas duomenų rinkimo metodas - pusiau struktūruotas interviu. Pusiau struktūruotą interviu sudare devyni klausimai, parengti tyrimo autorių, remiantis moksline ir profesine literatūra. Pirmieji du klausimai buvo ịvadiniai, penki skirti tyrimo problemos atskleidimui, du paskutinieji - baigiamojo tipo. Tyrimo metu surinktų duomenų analizè buvo atlikta aprašomosios ir turinio analizès metodais.

Tyrimo dalyviai. Tyrime dalyvavo 7 gydytojo odontologo 
padejejejos, kurių darbo patirtis - vieneri metai. Visos tyrimo dalyvès buvo moteriškos lyties. Vidutinis tyrimo dalyvių amžius - 21 metai, jauniausia tyrimo dalyvė 20 , vyriausia -22 metų. Visų tyrime dalyvavusių gydytojų odontologu padejejjų darbo patirtis - vieneri metai, visos dirba privataus tipo gydymo įstaigose (1 lentelè). Dvi tyrimo dalyvès dirba su vienu specialistu, o penkios - su ịvairių sričių specialistais. Išsamus tyrimo dalyvių charakteristikų aprašymas pateikiamas 1 lentelèje.

\section{Tyrimo rezultatai}

Pirmaisiais darbo metais patiriamo streso ypatumai. Stresas yra normali reakcija ị daugelị mus supančių aplinkybių, tačiau jis gali turèti tokių neigiamų pasekmių, kaip emocinis pervargimas ar perdegimas. Nuolat patiriamas stresas susijęs su padidèjusiu žmonių sergamumu, blogesne fizine sveikata, psichosomatiniais sutrikimais, mažesniu pasitenkinimu darbu, dažnesne darbo vietos kaita ir konfliktais darbo vietoje [11]. Teigiama, kad pagrindinès darbe patiriamo streso priežastys yra didelè atsakomybè, netolygus pareigu paskirstymas, didelis darbo krūvis, mažas atlyginimas, baimé prarasti darbą, nesaugumo jausmas, prasti santykiai su kolegomis, vadovo paramos ir pagalbos nebuvimas [2]. Dèl šių ir kitų priežasčių daugelis jaunų specialistų, vos tik pradejję dirbti, dažnai neatlaiko spaudimo, todèl per pirmuosius karjeros metus keičia savo specialybę ar jos kryptị [9]. Jaunus specialistus darbe dažnai lydi baimès jausmas, kuris atsiranda dèl darbo patirties ir žinių stokos, todèl daugelis darbuotojų kenčia nuo emocinio išsekimo ar patiria perdegimo sindromą, kuris skatina atsisakyti arba keisti turimą darbą [9]. Suomijoje atlikti tyrimai su slaugytojais rodo, kad per pirmuosius darbo metus apie 30 procentų slaugytojų palieka darbo vietą [7]. Pažymima, kad pirmaisiais darbo metais po studijų baigimo absolventai susiduria su daug emocinių, intelektinių iššūkių bei vaidmens pasikeitimu iš studento ị dirbančiojo [7]. Teigiama, kad pirmujų metų darbuotojai patiria realybès šoką, kai profesijos įsivaizdavimas neatitinka darbo realybès [8]. Kuo didesnis neatitikimas tarp turètų lūkesčių bei realybės, su kuria susiduriama darbo vietoje, tuo didesné tikimybé, jog per pirmuosius metus bus paliekama darbo vieta ar nusprendžiama keisti profesijos kryptị [7]. Tyrejai $[6,7]$ pastebi, kad sveikatos priežiūros darbuotojų realybės šoko tikimybe pirmaisiais darbo metais yra ypač didelè. Teigiama, kad sveikatos priežiūros darbuotojų profesinè veikla yra artimai susijusi su naujausių technologijų naudojimu, todèl aukštosios mokyklos nespejja paruošti absolventų darbui su naujausiomis technologijomis. Dèl šios priežasties jauni specialistai pirmaisiais darbo metais dažnai susiduria su profesinių igūdžių stoka - papildomu stresą keliančiu veiksniu darbe [6]. Kaip bus išgyvenamas realybės šokas pirmaisiais darbo metais, priklauso nuo igytos profesinès praktikos aukštojoje mokykloje [7]. Teigiama, jog labai svarbu, kad studentai, atlikdami profesinę praktiką, pamatytų kuo realistiškesnę profesinès veiklos kasdienybę, kad jiems būtų skiriama pakankama atsakomybe, kad studentai galètu pasijusti visaverčiais komandos nariais. Siekiant išpildyti tokias sąlygas, ypač svarbus praktikos vietoje skiriamo mentoriaus vaidmuo. Pažymima, kad pakankamos profesinès žinios bei ịgūdžiai, kolegų draugiškumas bei tikèjimas savo jègomis yra vieni iš svarbiausių veiksnių, siekiant sumažinti patiriamą stresą pirmaisiais darbo metais [7]. Atsparumas karjeros smūgiams pirmaisiais darbo metais priklauso ne tik nuo to, kaip aukštoji mokykla paruošia specialistą, tačiau ir nuo jo asmenybès. Pastebima, kad žmonès, kurie geba kovoti su iššūkiais, turi gerus problemų sprendimo bei socialinius igūdžius, domisi naujovèmis, nori padèti kitiems ir pasižymi optimistiniu požiūriu ị ateití, lengviau įveikia pirmujų darbo metų realybès šoką [8].

Apibendrinant galima teigti, jog patiriamas stresas pirmaisiais darbo metais kyla dèl profesinių lūkesčiu beatitikimo ir darbo realybès. Svarbi darbe patiriamo streso priežastis pirmaisiais darbo metais yra profesinių žinių ir igūdžių trūkumas. Sveikatos priežiūros darbuotojų tikimybè pirmaisiais darbo metais patirti aukštesnio lygmens su darbu susijusị stresą, yra didesnè, nei kitose srityse dirbančių asmenų.

Gydytojų odontologų padėjẻjų emocinè savijauta pirmaisiais darbo metais. Siekiant atskleisti gydytojų odontologų padejjëjų patiramo streso raišką pirmaisiais darbo metais

1 lentelè. Tyrime dalyvavusių gydytojų odontologų padejjèjų charakteristikų aprašymas

\begin{tabular}{|l|l|l|l|l|l|}
\hline $\begin{array}{l}\text { Infor- } \\
\text { manto } \\
\text { nu- } \\
\text { meris }\end{array}$ & Lytis & $\begin{array}{c}\text { Amžius, } \\
\text { metais }\end{array}$ & $\begin{array}{c}\text { Gydytojo } \\
\text { odon- } \\
\text { tologo } \\
\text { padėjèjo } \\
\text { darbo } \\
\text { patirtis, } \\
\text { metais }\end{array}$ & $\begin{array}{c}\text { Istai- } \\
\text { gos, ku- } \\
\text { rioje } \\
\text { dirba, } \\
\text { tipas }\end{array}$ & $\begin{array}{c}\text { Specialistu, } \\
\text { su kuriais } \\
\text { dirbama } \\
\text { odonto- } \\
\text { logijos } \\
\text { klinikoje, } \\
\text { skaičius }\end{array}$ \\
\hline 1. & Moteris & 22 & 1 & Privati & Keletas \\
\hline 2. & Moteris & 21 & 1 & Privati & 1 \\
\hline 3. & Moteris & 22 & 1 & Privati & Keletas \\
\hline 4. & Moteris & 21 & 1 & Privati & Keletas \\
\hline 5. & Moteris & 21 & 1 & Privati & Keletas \\
\hline 6. & Moteris & 21 & 1 & Privati & Keletas \\
\hline 7. & Moteris & 20 & 1 & Privati & 1 \\
\hline
\end{tabular}


odontologijos klinikoje, buvo atskleista nagrinėjamojo laikotarpio tiriamujų emocinè savijauta, išskirti darbe patiriamą stresą lemiantys veiksniai bei atskleisti gydytojų odontologų padejjejų naudojami darbe patiriamo streso mažinimo būdai.

Tyrimo metu surinktų duomenų analizè atskleide šešias grupes, geriausiai apibūdinančias gydytojų odontologų padèjejjų emocinę savijautą dèl darbe patiriamo streso: „nenoras nieko daryti“, „pakitę santykiai su artimaisiais“, išgyvenamų emocijų , ,išliejimas ant kitų žmonių“, „,nerimastingos mintys apie darbą ji pabaigus“, „,nenoras eiti ị darbą“, „,savęs nuvertinimas". Tyrimo dalyviai teigè, jog dèl darbe patiriamo streso pirmaisiais darbo metais jie išgyveno „nenoro nieko daryti“" jausmą. Ši jausma iliustruoja tokie tyrimo dalyviu pasisakymai: ,,atrodo, kad būdavo sèdèdavau namie ir net nenorédavau niekur eiti, net ị savo darba, nes žinodavau, kad grišiu pikta, pavargusi su ašarom akyse“, „pasidariau pikta ir nesinorejo nieko daryti“, ,,po darbo jausdavausi labai pavargusi ir tiesiog norédavosi tokio pasyvaus poilsio, nesinorëjo ten jokiu kitu dar pašaliniu veiklu, nes atrodo, kad tiesiog reikia pailsèti ir išsimiegoti“. Pastebèta, kad dèl darbe patiriamo streso kai kurie gydytojo odontologo padèjëjai prarado norą eiti ị darbą: ,,man eiti ị darba nebuvo nei menkiausio noro, èjau vos ne su ašarom ir su didžiausiu stresu, tiesiog i tai žiūrejjau kaip i pragara“. Tyrimo dalyviai nurodè, kad dèl darbe patiriamo streso pakito jų santykiai su artimaisiais: „,su namiškiais prasidèjo dideli pykčiai, kadangi buvau labai nervinga, taip pat ir su draugu buvo didžiuliai pykčiai vos neprivedè iki skyrybu vien dèl darbo valandu ir patiriamo streso darbe, tai buvo tikrai nemalonus laikotarpis“, „,su artimaisiais sumažédavo bendravimas, nes tiesiog nebesinorédavo jokio bendravimo“, „būdavau labai pikta ir irzli su artimaisiais ir kitais aplinkos žmonèmis". Pastebèta, jog darbe susikaupusią įtampą tyrimo dalyviai pradejjo dažniau išlieti ant kitų žmonių: „,išsiliedavau ant

2 lentelè. Kategorijos ir subkategorijos, apibūdinančios gydytojų odontologų padejejjų stresą lemiančius veiksnius pirmaisiais darbo metais

\begin{tabular}{|c|c|c|c|}
\hline $\begin{array}{l}\text { Katego- } \\
\text { rija }\end{array}$ & Santykiai & $\begin{array}{l}\text { Profesiniụ } \\
\text { igūdžių } \\
\text { trūkumas }\end{array}$ & $\begin{array}{c}\text { Gydytojo odon- } \\
\text { tologo padèjèjo } \\
\text { darbo specifikos } \\
\text { ypatumai } \\
\end{array}$ \\
\hline $\begin{array}{l}\text { Subka- } \\
\text { tegorija }\end{array}$ & $\begin{array}{l}\text { - Santykiai su } \\
\text { gydytoju odon- } \\
\text { tologu } \\
\text { - Santykiai su } \\
\text { kitais kolegomis } \\
\text { - Irsiliejimo i } \\
\text { kolektyvą pro- } \\
\text { blemos }\end{array}$ & $\begin{array}{l}\text { - Asistavimo } \\
\text { gydytojui odon- } \\
\text { tologui igūdžių } \\
\text { trūkumas } \\
\text { - Sunkumai stu- } \\
\text { dijų metu igytus } \\
\text { gebejjimus pritai- } \\
\text { kyti darbo vietoje }\end{array}$ & $\begin{array}{l}\text { - Gydytojo odon- } \\
\text { tologo padèjèjo } \\
\text { darbo daugia- } \\
\text { funkciškumas } \\
\text { - Didelis darbo } \\
\text { tempas }\end{array}$ \\
\hline
\end{tabular}

savo artimu žmoniu, išsiliedavau ir ant draugu, ir ant tèvu, bet jie suprasdavo mane, kad tiesiog tai dèl darbo ir bandydavo nuraminti“, „,norédavosi ant kažko išsilieti ta visa bloga emocija, kuria tu gaudavai darbe, išlieti i aplinka, kad nelaikyti savyje“, „, kai būdavo grižti pavargus po darbo, tai ir ant šeimos nariu šiek tiek kažkoki žodị ten pasakai, kurio gal nenorètum pasakyti“. Tyrimo dalyviai teige, kad dèl darbe patiriamo streso pradejo labiau nuvertinti save : „,galvoju gal aš čia tikrai nieko nemoku, gal čia tikrai aš nieko nesugebu tai tiesiog mažina pasitikejjima savimi ir tu galvoji, kad tikrai esi nevykus asistente “. Tyrimo rezultatai atskleide, kad pirmaisiais darbo metais tyrimo dalyviai galvodavo apie darbą ir jị pabaigę : „kasdieninejje veikloje kažkaip mintys daugiausia būna apie ta darba ar tikrai viska padariau, ar ten išéjus iš darbo tas pačias duris užrakinau ar visa sistema išjungiau".

Apibendrinant galime teigti, kad pirmaisiais darbo metais dèl darbe patiriamo streso gydytojų odontologų padejjejai jautė ,nenorą nieko daryti“", pablogėjo jų santykiai su artimaisiais, dažniau buvo linkę savo išgyvenamas neigiamas emocijas išlieti ant kitų žmonių, jautė nenorą eiti ị darbą, dažniau save nuvertindavo, gana dažnai galvodavo apie darbą net ji pabaigę.

Gydytojų odontologų padẻjẻjų stresą pirmaisiais darbo metais lemiantys veiksniai. Atlikus tyrimo metu surinktų duomenų analizę, buvo išskirtos trys kategorijos, nusakančios veiksnius, lemiančius gydytojų odontologų padejjèjų darbe patiriamą stresą pirmaisiais darbo metais: „,santykiai“", ,profesinių igūdžių trūkumas“, ,gydytojo odontologo padèjējo darbo specifikos ypatumai“" (2 lentelè).

„Santykių“" kategorija yra sudaryta iš trijų subkategorijų (2 lentelè): tai „santykiai su gydytoju odontologu“, „santykiai su kitais kolegomis“, ,isiliejimo ị kolektyvą problemos“. Tyrimo metu surinktų duomenų analizè atskleidè, kad vienas iš stresą keliančių veiksnių pirmaisiais darbo metais odontologijos klinikoje yra santykiai su gydytoju odontologu. Tyrimo dalyviai teigè, kad „mums kolegijoje visa laika sake, kad odontologo padejejas ir gydytojas yra viena komanda ir turi dirbti kartu, kad odontologo padejejas turi būti gydytojo dešinioji ranka, o čia taip nebuvo, čia buvo taip, kad aš buvau išnaudojama ir buvo visa laika kartojama ,tu privalai “, „, ne visi gydytojai vertina ta savo asistenta ir nesaugo jo, ir tikrai elgiasi su juo kaip su antrarūšiu kažkokiu ịrankiu darbo“, „, tas ryšys tarp asistento ir odontologo, ne visada būna tvirtas ir kartais odontologo asistentas taip büna truputi nužemintas". Tyrimo dalyviai teige, kad pirmaisiais metais dirbant kartu su gydytoju odontologu stresą keldavo prie paciento išsakoma kritika: ,tačiau ta jo suteikta man kritika, buvo tiesiogiai prie paciento, kai pacientas gulejo kèdeje, būdavo griežtu tonu pasakyta tai, kad pašiepti, pa- 
niekinti, pažeminti ir man tai labai nepatiko, nes vis dèl to ir pacientas tai girdèjo”, ,būdavo, kad ten siurbi tas pačias seiles, krauja tai chirurgas tiesiog išplèšia iš ranku siurbli ir pats siurbia, sako: ,,- ar tu nematai kur siurbti? “ Atliktuose interviu buvo minima, jog darbo atmosfera dažnai priklausydavo nuo gydytojo odontologo nuotaikos : ,labai priklausydavo nuo gydytojos ar ji buvo geroje nuotaikoje ar blogoje. Jei ji būdavo geros nuotaikos, tai viskas buvo gerai ir gera dirbti, ir linksma, bet jei ji būdavo blogoje nuotaikoje tai neduok Dieve, ne ta žodị pasakysi, ne ta kažka paruoši, tai čia buvo tiesiog galima bègti iš kabineto".

Analizuojant gydytojo odontologo padejejjo darbe stresą keliančius veiksnius pirmaisiais metais, santykių kategorijoje išskirta ir antroji subketegorija - santykiai su kitais kolegomis. Tyrimo dalyviai teige, kad pirmaisiais darbo metais stresą keldavo santykiai ir su kitais burnos priežiūros specialistų komandos nariais: , kita asistentè ị mane žiūrèjo kaip ị konkurentę, kad aš čia užimsiu jos vieta ir bandydavo man kaip ir pakenkti”, ,būdavo ir tu žmoniu, kurie tikrai stengdavosi igelti, nes tu esi jaunas žmogus ir niekas nesupranta, kad tu kartais tiesiog nespëji atlikti tam tikru darbu, tai büdavo ir tokiu darbuotoju, kurie stengdavosi pakenkti šiuo klausimu“.

Trečioji santykių kategorijoje išskirta subkategorija - įsiliejimo ị kolektyvą problemos. Interviu metu tyrimo dalyviai teigè, jog pirmaisiais metais darbe jie patirdavo papildomą stresą dèl problemų, kylančių ịsiliejant ị kolektyvą : „kolektyvas buvo senai susigyvenęs, ten visi vienas kita pažinojo, o aš buvau naujas žmogus, tai turbūt tas daugiausia stresa kèle“،, „pradžioje atrodè, kad labai šiltai mane priima, bet po to labai pasijuto, kad esu tokia kaip balta avis ten tarp ju juodu visu ir buvau apkalbinejama ir šiaip pradejjau jaustis nejaukiai büdama tarp jų", „,kai negali isilieti i kolektyva ir tau reikia kiekviena diena bendrauti su žmonèms su kuriais tu nenori bendrauti ir jie su tavim nesiskaito, tai labai sunku būti toje vietoje“. Tyrimo dalyviai nurode, kad issiliejimo i kolektyvą problemos kildavo ir dèl amžiaus skirtumo : „,gal kažkiek buvo keistoka, dèl to, kad kolektyve nebuvo mano amžiaus žmoniu, visi buvo vyresni, tačiau po kiek laiko issiliejau ir tiesiog pripratau bendrauti su tais žmonèmis".

Antroji veiksnių, lemiančių gydytojo odontologo padèjejo darbe patiriamą stresą, kategorija - ,profesinių ịgūdžių trūkumas". Šioje kategorijoje buvo išskirtos dvi subkategorijos: ,asistavimo ịgūdžiu gydytojui odontologui trūkumas“, „sunkumai studijų metu igytus gebejjimus pritaikant darbo vietoje“" (2 lentelè).

„Asistavimo ịgūdžių gydytojui odontologui trūkumo“" subkategoriją iliustruoja tokie tyrimo dalyvių pasisakymai kaip: , reiktu manau daugiau paskaitu kaip asistuoti tiesiog su pačiais atsiurbejjais, kaip dirbti, kaip juos laikyti“, , ,ne- buvo tas didžiausias stresas, kad aš esu užgauliojama ar žeminama to daktaro, buvo didžiausiais stresas, kad aš nemoku, neturiu tu žiniu ir mane daktaras peikia, o aš ir nemoku ir kai mane papeikia aš nežinau ka man daryti, aš pasimetu, kyla stresas". Atlikus duomenų analizę pastebèta, kad pirmaisiais darbo metais papildomas stresas atsiranda ir dèl kylančių „sunkumų studijų metu igytus gebejjimus pritaikant praktikoje“: , praktikos stoka buvo kadangi vis tiek pirmi darbo metai, tai patyriau tikrai labai daug streso”, ,trūko žiniu ir neturèjau galima sakyti jokios praktikos dirbant šiam darbe $<$... >galima sakyti visko ten ir teko išmokti, dèl to buvo labai sunku pradžioje“, ,teorines žinias reikia pritaikyti praktikoje, reikia pritaikyti ir naujoje darbo vietoje“.

Trečioji veiksnių, lemiančių darbe patiriamą stresą kategorija, - ,gydytojo odontologo padejèjo darbo specifiškumas". Šioje kategorijoje buvo išskirtos dvi subkategorijos: "gydytojo odontologo padejejjo darbo daugiafunkciškumas“ ir „didelis darbo tempas“ (2 lentelè).

Tyrimo dalyviai teigé, kad pirmaisiais darbo metais daug streso kèlè tai, jog padejjèjas vienu metu turi atlikti daug ịvairaus pobūdžio užduočių, darbo eiga yra neprognozuojama. „Gydytojo padejejejo darbo daugiafunkciškumo" subkategoriją geriausiai iliustruoja šie pasisakymai: ,, odontologo padejejas savo darbe tikrai labai daug atsakomybès turi ir ne vien, kad gydytojui padeti ir asistuoti, bet ir šiaip visos dokumentacijos, bendravimas su pacientais ir panašiai, tai maniau, kad nebus tiek galbūt darbo, bet tikrai yra daug daugiau visko nei isivaizdavau“, „, teko kelis kartus dirbti per keturis gydytojus, kas yra praktiškai neimanoma, tačiau tekdavo ne pagrinde sèdèti prie gydytojo ir jam asistuoti, bet tiesiog nešti medžiagas, tvarkyti darbo vieta, kviesti pacientus, pildyti dokumentacija ir panašiai“, „,kiekviena diena, nežinai kas ateis, kokia bus paciento burnos būklè, ka tau teks daryti, ka gydytojui teks daryti, kokiu medžiagu gali pritrūkti ir panašiai".

Tyrimo metu surinktų duomenų analizè atskleidè, kad vienas iš stresą keliančių veiksnių „,didelis darbo tempas“: ,,dažniausiai laiko būdavo per mažai, pacientui paprastai skirdavo po valanda laiko, tai jeigu naujas pacientas tarkim jam reikia dokumentacija, pirminès apžiūros, visa ta supildyti, visq informacija susirinkti“, „, sédi, asistuoji ir atrodo, kad tu jau turi baigti darba, priimti kita pacienta, o tau dar reikia ji išleisti, sédinti kèdeje, sutvarkyti viska ir tik tada priimti sekanti, tai tas irgi stresa kelia tikrai“", ,manau, kad didelis darbo krūvis, tempas, kada pacientai eina vienas paskui kita, gydytojas tarkim vèluoja atlikti savo procedūra, tuo tarpu asistentas turi suspèti tiek prie gydytojo stovéti procedūros metu, tiek sutvarkyti tarkim instrumentus, tiek aptarnauti pati pacienta po procedūros, tarkim paduoti jam kokius vaistus, pinigus paimti iš jo, tai ko gero tai tikrai sukelia stresa“". 
Gydytojų odontologo padėjējų naudojami streso mažinimo būdai pirmaisiais darbo metais. Atlikus duomenų analizę, buvo išskirti šie gydytojų odontologų padejejjų naudojami streso mažinimo būdai pirmaisiais darbo metais: fizinè veikla, pozityvus mąstymas ir minčių nukreipimas, poilsis, užsièmimas mègstama veikla. Tyrimo dalyviai teigè, jog darbe patiriamą stresą jiems padeda sumažinti fizinè veikla: ,jeigu jau būna labai bloga diena, ir jaučiuosi tokia išsekusi emociškai, tai einu i sporto kluba ir ten išsikraunu kaip sakant", , ,iš tikruju užsiiminejju sportu, tai būtent kai yra šiltesnis sezonas, mégstu bègioti kas man iš tikruju labai padeda sumažinti stresa, padeda atsipalaiduoti“. Kiti tyrime dalyvavę odontologo padejjejjai teigè, jog darbe patiriamą stresą jiems padeda ịveikti pozityvus mąstymas ir minčių nukreipimas: ,jau labai prastai būna tu sustoji, nutyli ir tiesiog ramiai kvépuoji, ir turbūt save ramini, kad viskas gerai, čia greit praeis“, „, stengiuosi nukreipti savo mintis, apie kažka gero galvoti, nusiraminti ir tiesiog galvoti apie tai “, , bandydavau vis galvoti, kad aš darau viska gerai, kad aš stengiuosi viska atlikti gerai, kad aš tikrai stengiuosi dirbti ir padeti savo daktarui“". Darbe patiriamą stresą kai kurie tyrimo dalyviai mažina užsiimdami mègstama veikla : ,iš tikro man labiausiai padeda vairavimas, nes labai mégstu vairuoti ir taip pat buvimas su draugais, tai labiausiai padejo“, „grįzusi namo iš tikruju stengiuosi užsiimti man patinkančia veikla arba susitikti su drangais, kurie tiesiog nukreipty mintis nuo visos tos darbo dienos ir tiesiog praleisti laika kažkaip kitaip “. Kai kurie tyrimo dalyviai teigè, kad darbe patiriamą stresą padèda ịveikti tiesiog poilsis: , tiesiog poilsis ir atsipalaidavimas nuo darbo, tiesiog negalvoti apie tai“, „tiesiog stengdavausi gerai išsimiegoti, pailsèti, atsipalaiduoti kažkaip, stengtis negalvoti apie darba, palikti viska darbe".

Apibendrinant galime teigti, kad gydytojų odontologų padejejjai pirmaisiais darbo metais naudojo šiuos darbe patiriamo streso mažinimo būdus: fizinè veikla, pozityvus mąstymas ir minčių nukreipimas, poilsis, užsièmimas mègstama veikla.

\section{Išvados}

1. Pirmaisiais darbo metais stresas patiriamas dèl profesinių lūkesčių neatitikimo ir darbo realybès. Svarbi darbe patiriamo streso priežastis pirmaisiais darbo metais yra profesinių žinių ir ịgūdžių trūkumas. Sveikatos priežiūros darbuotojų tikimybė pirmaisiais darbo metais patirti aukštesnio lygmens su darbu susijusi stresą yra didesné, nei kitose srityse dirbančių asmenų.

2. Pirmaisiais metais dèl streso darbe gydytojų odontologų padejjèjai jaute „,nenorą nieko daryti“, pablogèjo jų santykiai su artimaisiais, dažniau buvo linkę savo neigiamas emocijas išlieti ant kitų. Pastebèta, kad gydytojų odontologų padejejjai pirmaisiais darbo metais jautè nenorą eiti ị darbą, dažniau save nuvertindavo, gana dažnai galvodavo apie darbą net ir ji pabaigę.

3. Gydytojų odontologų padejejejams pirmaisiais darbo metais daugiausia streso kèle santykiai su gydytoju odontologu bei kitais kolegomis, įsiliejimo ị kolektyvą problemos, profesiniu ịūdžių trūkumas, didelis darbo tempas ir darbo daugiafunkciškumas.

4. Gydytojų odontologų padejjejjai pirmaisiais darbo metais naudojo šiuos darbe patiriamo streso mažinimo būdus: fizinè veikla, pozityvus mąstymas ir minčių nukreipimas, poilsis, užsièmimas mègstama veikla.

\section{Literatūra}

1. Bonczek ME, Quinlan-Colwell A, Tran S, Wines K. A holistic approach to improve nursing retention during the first year of employment. Nursing Administration Quarterly 2016; 40(3): 269-275.

https://doi.org/10.1097/NAQ.0000000000000178

2. Burba B, Sitnikovas O, Lankaite D. Streso pasireiškimas, dažniausi stresą sukeliantys veiksniai, distreso valdymas tarp Lietuvos apsaugos darbuotojų. Medicinos teorija ir praktika, 2014; 20 (1): 14-20.

3. Florea R, Florea R. Individual and organizational implications of work-related stress. Economy Transdisciplinarity Cognition 2016; 19(1): 28-33.

4. Geun HG, Redman RW, McCullagh MC. Predictors of turnover among Asian foreign-educated nurses in their 1st year of US employment. The Journal of Nursing Administration/ JONA 2018; 48(10): 519-525.

https://doi.org/10.1097/NNA.0000000000000660

5. Grover S, Sahoo S, Bhalla A, Avasthi A. Psychological problems and burnout among medical professionals of a tertiary care hospital of North India: a cross-sectional study. Indian Journal of Psychiatry 2018; 60(2): 175-188.

https://doi.org/10.4103/psychiatry.IndianJPsychiatry_254_17

6. Harris A. First-year employment experiences of entry-level radiologic technologists (Doctoral dissertation). Capella University 2018.

7. Kaihlanen AM, Haavisto E, Strandell-Laine C, Salminen L. Facilitating the transition from a nursing student to a registered nurse in the final clinical practicum: a scoping literature review. Scandinavian Journal of Caring Sciences 2018; 32(2): 466-477. https://doi.org/10.1111/scs.12494

8. Kodama M. Functions of career resilience against reality shock, focusing on full-time employees during their first year of work. Japanese Psychological Research 2018;59(4): 255-265. https://doi.org/10.1111/jpr.12161

9. Labrague LJ, McEnroe-Petitte DM. Job stress in new nurses during the transition period: an integrative review. International 
Nursing Review 2017; 65(4): 491-504.

https://doi.org/10.1111/inr.12425

10. McCombie RP, Antanavage ME. Transitioning from occupational therapy student to practicing occupational therapist: first year of employment. Occupational Therapy in Health Care 2017; 31(2):126-142.

https://doi.org/10.1080/07380577.2017.1307480

11. Rovas L, Lapėnienė J, Baltrušaitytė R. Slaugytojų darbe patiriamas stresas ir jo ịveika. Visuomenès sveikata, 2012;1: 80-85.

12. Šatrauskaitė R, Tamulienė R, Mačiulienė D. Gydytojų odontologų padejejjų darbe patiriamas stresas. Sveikatos mokslai, 2014; 6(24): 51-56.

https://doi.org/10.5200/sm-hs.2014.112

\section{DENTAL ASSISTANT'S WORK-RELATED STRESS: FIRST-YEAR EXPERIENCE IN DENTAL CLINIC \\ R. Tamulienė, E. Gedeikytė, D. Mačiulienė}

Keywords: dental assistant, work-related stress, first-year employment.

Summary

The aim of this study was to reveal how work-related stress is experienced during the first year of employment among dental as- sistants. Seven dental assistants, who have one-year work experience, took part in the research. Data were collected by using semistructured interviews. Content and descriptive analysis were used for the analysis of the research data. The results of the research have showed that dental assistants during their first year of employment had the feeling of "don't want to do nothing", their relationships with relatives become more complicated, their tent to have lower self-esteem and very often were thinking about the work after finishink it. The results of the research showed that work-related stress during the first-year employment of the dental assistants are caused by these factors: relationships with doctor and other collogues, problems by intergrating to work team, the lack of professional knowledge and skills and dental assistants' work multifunctionality and high intensity of it.

Correspondence to: rasa.tamuliene@go.kauko.lt

Gauta 2020-10-12 